\title{
$\begin{array}{lllllllllllll}A & R & T & \text { I } & C & \mathrm{~L} & \mathrm{E} & \mathrm{S}\end{array}$
}

\section{The Link Between Job Satisfaction and Firm Value, With Implications for Corporate Social Responsibility}

by Alex Edmans

\section{Executive Overview}

How are job satisfaction and firm value linked? I tackle this long-standing management question using a new methodology from finance. I study the effect on firm-level value, rather than employee-level productivity, to take into account the cost of increasing job satisfaction. To address reverse causality, I measure firm value by using future stock returns, controlling for risk, firm characteristics, industry performance, and outliers. Companies listed in the "100 Best Companies to Work For in America" generated $2.3 \%$ to 3.8\% higher stock returns per year than their peers from 1984 through 2011 . These results have three main implications. First, consistent with human resource management theories, job satisfaction is beneficial for firm value. Second, corporate social responsibility can improve stock returns. Third, the stock market does not fully value intangible assets, and so it may be necessary to shield managers from short-term stock prices to encourage long-run growth.

$\mathrm{T}$ he link between job satisfaction and firm value is of great interest to both academics and practitioners. It has implications for how managers approach employee recruitment, retention, and motivation, and more generally speaks to the importance of human resource management (HRM) for a firm's overall business strategy. Indeed, Landy (1989) described this relationship as the "Holy Grail" of organizational behavior. But there is still much debate on whether these variables are actually related in practice. This paper aims to tackle this old question-a predominantly management topicwith a new methodology from the finance literature.

\section{The Link in Theory}

The theoretical benefits of job satisfaction are reasonably clear. HRM theories (e.g., Becker \&
Gerhart, 1996; Likert, 1961; McGregor, 1960; Pfeffer, 1994) suggest several channels through which job satisfaction can improve firm value. One is recruiting and retaining key employees. The resource-based view (RBV) of the firm (Barney, 1986; Wernerfelt, 1984) argues that firms develop sustainable competitive advantage by building resources that are both valuable and hard for competitors to poach. HRM theories assert that employees are indeed valuable. They are the key source of value creation in the modern firm, particularly in knowledge-based industries such as pharmaceuticals and software. However, satisfying the latter requirement-being hard to poach-is difficult because talented employees can walk out of the door. This is where the role of job satisfaction lies. A satisfying workplace can foster job

\footnotetext{
Alex Edmans (aedmans@wharton.upenn.edu) is an Assistant Professor of Finance at The Wharton School of the University of Pennsylvania, a Faculty Research Fellow at the National Bureau of Economic Research, and a Research Associate at the European Corporate Governance Institute.
} 
embeddedness (Mitchell, Holtom, Lee, Sablynski, $\&$ Erez, 2001) and ensure that talented employees stay with the firm. Relatedly, job satisfaction can provide a valuable recruitment tool.

A second channel through which job satisfaction can improve firm value is through worker motivation. Under Taylorism (Taylor, 1911), motivation could be achieved by extrinsic factors such as piece pay or the threat of firing. This approach worked because employees' output was easy to measure-for example, the number of widgets produced. Nowadays, workers' tasks, such as building client relationships and mentoring subordinates, are much harder to quantify. Thus, providing incentives based on output may be ineffective or even destructive (Kohn, 1993). Since extrinsic motivators are less effective, this increases the role for intrinsic motivators such as satisfaction. Organ's (1977) social exchange model argues that an employee views pleasant working conditions as a "gift" from the firm, and responds with a "gift" of increased effort-even if effort is not directly rewarded by an incentive scheme. Job satisfaction can promote organizational citizenship behavior (Organ, 1988), where an employee goes above and beyond the formal requirements of the job and internalizes the firm's objective function as his or her own.

\section{The Link in Practice}

While the benefits of job satisfaction are clear in theory, empirically documenting them in practice is much harder. Most studies investigate the correlation between job satisfaction and individual job performance (rather than firm value), measuring satisfaction using a survey. An early meta-analysis by Brayfield and Crockett (1955) concluded that there was "minimal or no relationship" between the two; Vroom (1964) and Locke (1965) later showed similar findings. While these conclusions may have been driven by the relative lack of studies in the 1950s and 1960s, Iaffaldano and Muchinsky (1985) meta-analyzed 217 correlations from 74 studies and found a mean correlation of only 0.17 . They concluded that job satisfaction and job performance are "only slightly related to each other," dubbing the relationship an "illusory correlation" and a "management fad."
This meta-analysis proved highly influential and pervaded management thinking for the rest of the millennium. In particular, it was widely cited as evidence that there is no link between satisfaction and performance.

Recent studies have uncovered more positive results. An updated meta-analysis by Judge, Thoresen, Bono, and Patton (2001) found a mean correlation of 0.30 . Studying the related concept of happiness/positive affect, Barsade and Gibson (2007), Fisher (2010), and Lyubomirsky, King, and Diener (2005) found a positive link with individual success. While these studies are at the individual level, the study of Ostroff (1992) and the meta-analyses of Harter, Schmidt, and Hayes (2002) and Harter, Schmidt, Asplund, Killham, and Agrawal (2010) argued that the organization is the appropriate unit of analysis as it takes into account interactions between workers. All three found stronger positive correlations than individual-level analyses. While the above analyses investigated performance, Allen, Bryant, and Vardaman (2010), Griffeth, Hom, and Gaertner (2000), and Lee, Mitchell, Holtom, McDaniel, and Hill (1999) showed a negative link between satisfaction and employee turnover, providing evidence for the retention benefits of job satisfaction discussed earlier.

A separate but related literature studies the link between firm performance and high-performance work practices (Huselid, 1995) or high-performance workplace systems (HPWS) (Becker \& Huselid, 1998). Job satisfaction is an output measure-an attitudinal variable that is not directly controlled by management but indirectly affected through changing HRM policies. In contrast, an HPWS is an input measure-a set of practices that strategic HRM theorists consider performance enhancing, such as incentive compensation and employee participation. These practices are controlled by management and are an input into job satisfaction; indeed, job satisfaction is a potential channel through which HPWSs can improve firm performance.

Huselid (1995) showed that HRM practices are correlated with lower turnover and, on a peremployee basis, higher sales, market value, and profits. Perceived organizational performance is 
positively linked to HRM practices (Delaney \& Huselid, 1996) and work-family programs (PerrySmith \& Blum, 2000); Konrad and Mangel (2000) found a positive association between worklife programs and firm productivity. More broadly, the review paper by Pfeffer and Veiga (1999) detailed the various theoretical benefits of HPWSs and cited supporting evidence. Combs, Liu, Hall, and Ketchen (2006) meta-analyzed 92 studies and found an overall correlation between HPWSs and firm performance of 0.2 .

\section{Difficulties in Identifying an Effect}

The positive correlations reported by recent research cannot be automatically interpreted as evidence that job satisfaction improves firm value. First, positive correlation could result from reverse causality from performance to satisfaction, since most of the above studies are cross-sectional. It could be that performance directly causes satisfaction (employees are happier working for a successful firm), or that strong performance allows managers to increase wages and benefits, which in turn raises satisfaction. It is tempting to try to address reverse causality by undertaking longitudinal studies that lag the satisfaction measure (e.g., by relating satisfaction in 2001 to performance in 2002) and arguing that satisfaction must have caused performance because it preceded it. But it may be that satisfaction in 2001 was a result of strong performance in 2001, and this strong performance in 2001 also led to strong performance in 2002 because performance is persistent. In short, the correlation between satisfaction in 2001 and performance in 2002 could arise because a third omitted variable (performance in 2001) drives both. ${ }^{1}$

Second, the above studies typically focus on job performance as the dependent variable, but this is critically different from firm value for three reasons. First, if job performance is measured at the individual level, it is unclear how this aggregates at the firm level. It could be that there is a positive

\footnotetext{
${ }^{1}$ Studying the change in performance between 2001 and 2002 is not a solution either, as changes in performance are usually correlated over time. An improvement in performance between 2001 and 2002 could be caused by an improvement in performance between 2000 and 2001 (which also leads to satisfaction in 2001).
}

correlation between individual satisfaction and individual performance on average, but this is driven by low-level workers and the correlation is negative for senior managers. Since the latter are more important for firm value, the overall link to firm performance could be negative. Second, even considering organizational performance, there are several possible dimensions-such as productivity, absenteeism, and turnover-and it is unclear how to weight them. For example, if satisfaction is correlated with higher productivity but also higher turnover, it is unclear whether satisfaction is beneficial overall. Similarly, it is unlikely that a study will be able to analyze every single dimension of performance that is relevant to firm value; it may omit some important ones.

Third, some performance measures do not take into account the costs of achieving higher job satisfaction. Even if job satisfaction improves job performance, it may still reduce firm value net of costs. Cappelli and Neumark (2001) found that "high-performance" practices, which delegate responsibility to employees, increase labor costs. Thus, even though they also found weak evidence of improved productivity, there is no effect on overall labor efficiency (output per dollar cost). Moreover, the cost of increasing job satisfaction may include not only direct financial expenses, but also increased risk. Firms with high job satisfaction are often human capital-intensive, making them vulnerable to market downturns because human capital has little value in bankruptcy. While a profit measure (such as earnings) takes financial expenses into account, it does not consider risk; indeed, there is no accepted way to adjust accounting variables for risk.

While most papers study firm performance, a few do analyze firm value. Abowd (1989) showed that announcements of pay increases reduce market valuations dollar for dollar. Diltz (1995) found that stock returns are uncorrelated with the Council on Economic Priorities (CEP) minority management and women in management variables, and are negatively correlated with family benefits. Dhrymes (1998) found no relationship with KLD's employee relations variable, and Gorton and Schmid (2004) showed that greater employee involvement reduces firm value. These results are 
consistent with the view of job satisfaction held by the economics and finance literatures: Companies maximize their profits by ensuring that employees are paid no more than their outside option, and so providing them with "excess" satisfaction is costly to shareholders. Practitioners also emphasize the costs of creating a satisfying workplace: Tsao (2003) in BusinessWeek and Zimmerman (2004) in the Wall Street Journal discussed investors' concerns that Costco offers excessively generous pay and benefits to employees, compared to its frugal competitor Wal-Mart. The title of Zimmerman's article, "Costco's Dilemma: Be Kind to Its Workers, or Wall Street," captures the zero-sum view that job satisfaction is necessarily at the expense of firm value.

\section{This Paper's Approach}

T This paper's methodology aims to address both of the above concerns: reverse causality, and the need to measure firm value rather than firm performance. It uses a measure of firm value: the stock market value. In an efficient market, the market value eventually takes into account all publicly available information that is relevant for firm value. How important a variable is can be measured by its dollar effect on the stock market value (Fama, 1970). The market value takes into account all the channels through which job satisfaction affects firm value, weighting them according to their relative importance, and also considers costs. For example, assume that job satisfaction leads to high employee turnover, but higher turnover reduces firm value by only $\$ 5$ million (since the high turnover is only for low-level workers). Assume also that job satisfaction leads to high productivity among senior managers, which increases firm value by $\$ 50$ million, and that the cost of the job satisfaction program is $\$ 20$ million. Eventually, the overall increase in market value will be $\$ 25$ million.

However, simply studying the firm's current market value runs into two issues. First, it is still subject to reverse causality - a high current market value could lead to high satisfaction. Thus, I instead study future stock returns-by relating satisfaction in December 2001 to stock returns in 2002, for example. The stock return in 2002 is the change in the market value between December 2001 and December 2002. Notably, unlike other performance measures, stock returns are not persistent: The change in market value between 2001 and 2002 is unrelated to the change in market value between 2000 and 2001 in an efficient market. ${ }^{2}$ If satisfaction in December 2001 was caused by strong performance in 2001, the market value would already be high in December 2001 and so we should not expect high returns in 2002.

Second, the market may not incorporate the full benefits of job satisfaction immediately. While it should incorporate tangible information such as performance immediately, it may take time to incorporate intangible information such as job satisfaction, as it is difficult to quantify its impact on firm value. Thus, a firm's satisfaction in December 2001 may not be fully incorporated into its value by December 2001, but may affect the market value only when it leads to future tangible outcomes that are directly valued. If job satisfaction in December 2001 leads to employees being productive and the firm announcing high earnings in June 2002, the stock price will increase in June 2002. The company's stock return between December 2001 and December 2002 will capture this earnings announcement. Importantly, the use of stock returns captures all possible channels, not just earnings, through which job satisfaction may affect firm value. Other channels include a new product launch, positive customer satisfaction ratings announced in the press, positive Wall Street analyst reports, the signing of a new contract, or the filing of a patent. ${ }^{3}$ In sum, studying future stock returns allows for the possibility that the market takes time to recognize the benefits of job satisfaction.

A further benefit is that using stock returns lets us control for risk. While stock returns are rarely used in the management literature, they are fre-

\footnotetext{
${ }^{2}$ If the market is inefficient, stock returns may be persistent due to "momentum" effects. As described later, I control for momentum.

${ }^{3}$ Of course, it is difficult for the stock market to estimate the impact of some of these outcomes on overall value precisely. However, the use of market values does not assume that the market estimates the value of every outcome precisely_only that it forms an unbiased estimate that is equally likely to be an overestimate as an underestimate. If a new product launch leads to the market value rising by $\$ 100$ million, this implies that the true value of the product is just as likely to be $\$ 110$ million as $\$ 90$ million.
} 
quently studied by the finance literature. This literature has developed well-established empirical techniques - in particular, to control for riskfrom which this paper draws. In contrast, there is no accepted way to adjust other measures of firm performance for risk.

\section{The Best Companies List}

l measure job satisfaction using the list of the "100 Best Companies to Work for in America." This list was first published in a book in March 1984 (Levering, Moskowitz, \& Katz, 1984) and updated in February 1993 (Levering \& Moskowitz, 1993). Since 1998, it has been published in the January issue of Fortune magazine each year. The list has been overseen by Robert Levering and Milt Moskowitz throughout its 28-year existence, and is compiled by the Great Place to Work ${ }^{\circledR}$ Institute in San Francisco. ${ }^{4}$

A firm's ranking in the Best Companies list comes from two sources. Two-thirds of the score comes from employee responses to the Trust Index ${ }^{\odot}$ employee survey. The survey questions were developed through an extensive process that involved a review of academic literature; interviews with managers, employees, and workplace experts; focus group sessions; and discussions with management consultants, survey design experts, and researchers. This process created 120 statements, which were narrowed down to 57 following extensive testing with groups of employees, postsurvey interviews, and cluster and factor analysis. The survey was then beta-tested in a variety of workplace settings to ensure that each survey statement was measuring correctly.

The final 57 statements span five categories: credibility, respect, fairness, pride, and camaraderie. The first three concern workers' trust in management, the fourth concerns workers' perceptions of the job, and the fifth concerns workers' relationships with other employees. Indeed, the Insti-

${ }^{4}$ Although the Institute was not founded until 1990, Levering and Moskowitz used the same criteria for the 1984 list, although they surveyed employees directly rather than through a questionnaire. The interviews used for the 1984 list were the primary basis for the subsequent questionnaire. Indeed, when the Trust Index was first used, it replicated the results that Levering and Moskowitz had obtained when they conducted interviews for their 1984 list. tute defines a "great place to work" as one where "employees trust the people they work for, have pride in what they do, and enjoy the people they work with." Employees provide ratings on a scale of 1 to 5 and answer two open-ended questions. The survey statements are proprietary and not generally made public; the Institute kindly provided them for this paper (the questions, but not individual responses). Table 1 provides a sub- T1 sample of survey questions. Across all levels of employees, 250 are randomly selected in each firm; respondents fill in the surveys anonymously and return their responses directly to the Institute. The response rate is around $60 \%$.

The remaining one-third of the score comes from the Culture Audit ${ }^{\odot}$. This is a questionnaire completed by management-similar to the survey instruments used by the HPWS literature to evaluate a firm's HRM practices-on the firm's demographic makeup, pay and benefits programs, and culture. Again, the questions are proprietary, and the Institute kindly provided them for this paper. They include the following topics: diversity (proportion of women and minorities in senior positions), turnover (voluntary, involuntary, and retirements), compensation (average cash compensation, retirement benefits, employee stock ownership plans, stock options, profit sharing), benefits (health care, training, on-site perks), time off (paid vacations, sabbaticals, community involvement), and work-family issues (parental leave, child care). The audit also includes numerous open-ended questions, examples of which are given in Table 2.

The Best Companies list has several advantages as a measure of firm-level job satisfaction. First and most important is that we have data on stock returns of the Best Companies for a 28-year period that includes both recessions and booms. This time series is substantially longer than those used in prior literature, which typically considers one point or, at most, a couple of years. This length helps ensure that the results are not driven by a specific time period or market conditions (e.g., it may be that job satisfaction is valuable only in recessions). Second, some previous studies focus on individual dimensions of job satisfaction, such as pay satisfaction or coworker satisfaction. This 


\section{Table 1}

\section{Trust Index Survey Questions}

\begin{tabular}{|l|l|l|l|}
\hline Dimension & \multicolumn{1}{|c|}{ Subdimension } & \multicolumn{1}{|c|}{ Sub-subdimension } & \multicolumn{1}{c|}{ Statement } \\
\hline Credibility & Two-way communication & Informative communication & Management keeps me informed about important issues and changes. \\
\hline & & Accessible communication & I can ask management any reasonable question and get a straight answer. \\
\hline & Competence & & \\
\hline & Integrity & & \\
\hline & Support & & \\
\hline & Collaboration & Work environment & This is a psychologically and emotionally healthy place to work. \\
\hline & Caring & Personal life & Management shows a sincere interest in me as a person, not just an employee. \\
\hline Fairness & Equity & Pay & I feel I receive a fair share of the profits made by this organization. \\
\hline & & Membership & Everyone has an opportunity to get special recognition. \\
\hline & Impartiality & & \\
\hline & Justice & & \\
\hline Pride & Personal & & \\
\hline & Team & & I'm proud to tell others I work here. \\
\hline & Corporate Image & [None] & \\
\hline Camaraderie & Intimacy & & This is a fun place to work. \\
\hline & Hospitality & Enjoyment & When you join the company, you are made to feel welcome. \\
\hline & & Welcome & \\
\hline & Community & & \\
\hline
\end{tabular}

Notes: This table provides sample survey questions in the Great Place to Work Institute's survey of the "100 Best Companies to Work For in America." Each dimension is divided into several subdimensions; in most cases, each subdimension is subdivided into several sub-subdimensions, and there are several statements for each sub-subdimension. For the Credibility, Respect, Fairness, and Camaraderie dimensions, I choose one subdimension and provide one statement relating to each of the sub-subdimensions. For the Pride dimension, there are no sub-subdimensions, so I provide one statement relating to one of the subdimensions. All survey questions are copyrighted by the Great Place to Work Institute.

approach has similar problems to analyzing individual performance rather than overall firm value: It may miss some important dimensions of job satisfaction, and it is unclear how to weight the various components. (In particular, the researcher has freedom to weight them as he wishes to produce the desired results.) In contrast, the Best Companies list is a thorough measure of overall job satisfaction that involves surveying several dimensions. It is arguably the most respected and prominent measure available; as a result, it receives significant attention from shareholders, management, employees, and the media. The Trust Index has been used by thousands of corporations in nearly 30 countries worldwide. Third, it covers large companies (median market value of $\$ 5$ billion in 1998), which are especially important for the overall economy.

The Best Companies list does have some lim-
Table 2

\section{Culfure Audit Survey Questions}

\begin{tabular}{|l|l|}
\hline \multicolumn{1}{|c|}{ Topic } & \multicolumn{1}{c|}{ Question } \\
\hline Inspiring & $\begin{array}{c}\text { How do you inspire employees to feel that their work has } \\
\text { more meaning than being "just a job"? }\end{array}$ \\
\hline Speaking & $\begin{array}{c}\text { What are the distinctive ways in which management ... } \\
\text { shares information .. . with employees? }\end{array}$ \\
\hline Listening & $\begin{array}{c}\text { What avenues are available for employees to communicate } \\
\text { with management? }\end{array}$ \\
\hline Thanking & $\begin{array}{c}\text { How does your company show appreciation and/or } \\
\text { recognition for employees' good work and extra effort? }\end{array}$ \\
\hline Caring & $\begin{array}{c}\text { Please describe any special or unique benefits/perks } \\
\text { that you offer. }\end{array}$ \\
\hline Celebrating & In what ways does your company celebrate its successes? \\
\hline
\end{tabular}

Note: This table provides a subsample of questions in the Open-Ended Questions section of the Culture Audit. There are more topics than those listed here, and for some topics, there is more than one question. The actual questions are significantly more detailed than listed here; for brevity, I provide only an abridged version of each question. All survey questions are copyrighted by the Great Place to Work Institute. 
itations, however. One potential concern is that only two-thirds of a firm's score comes from employee responses to the Trust Index; the remaining one-third comes from management responses to the Culture Audit. (The individual results of the Trust Index and Culture Audit are not available.) Thus, the list is not a "pure" measure of job satisfaction as reported by employees, but rather a measure of workplace quality, which also contains management's statement of actual practices. This is not a problem if employee and management responses are highly correlated. In addition, including management responses can have advantages (Kruse, Blasi, \& Freeman, 2012). Managers may be aware of workplace benefits that an employee is unaware of (an employee who has not yet had children may not be aware of the parental leave policy, for instance), but that she will learn about in time and that will affect her motivation and retention. Firm-level turnover data likely provides a more accurate overall picture than an individual employee's statement of intent to stay with the firm. For brevity, I use the phrase "job satisfaction" to capture the overall workplace quality measured by the Best Companies list.

A second limitation is that the Great Place to Work Institute does not survey all companies. Firms must apply to be considered for the list; around 400 do so each year. (The Institute does not make available the firms that applied and failed to make the list.) Such selection issues either have no effect or (more likely) bias the results downward. If a firm with low satisfaction does not apply because it expects not to make the list, this simply increases the list's accuracy. If a firm with high satisfaction does not apply because this attribute is already well-known and it does not need independent verification, this reduces the satisfaction level of the firms in the list and weakens the results. If 30 of the "true" top100 firms choose not to apply, the list will end up containing 100 of the top 130 firms, rather than the top 100 firms, attenuating the findings.

Table 3 details the number of Best Companies each year that had stock returns available from the Center for Research in Security Prices (CRSP) in at least one month before the next portfolio for-
Table 3

\section{Summary Statistics}

\begin{tabular}{|l|c|c|c|}
\hline Year of list & Best companies & Added & Dropped \\
\hline 1984 & 78 & & \\
\hline 1993 & 69 & 30 & 39 \\
\hline 1998 & 70 & 34 & 33 \\
\hline 1999 & 68 & 26 & 28 \\
\hline 2000 & 60 & 20 & 28 \\
\hline 2001 & 55 & 15 & 20 \\
\hline 2002 & 55 & 13 & 13 \\
\hline 2003 & 61 & 14 & 8 \\
\hline 2004 & 57 & 11 & 15 \\
\hline 2005 & 58 & 11 & 10 \\
\hline 2006 & 50 & 8 & 16 \\
\hline 2007 & 47 & 10 & 13 \\
\hline 2008 & 42 & 11 & 16 \\
\hline 2009 & 40 & 8 & 10 \\
\hline 2010 & 39 & 7 & 8 \\
\hline 2011 & 39 & 6 & 6 \\
\hline
\end{tabular}

Note: The second column details the number of the "100 Best Companies to Work For in America" that had returns available on CRSP for at least one month between publication of the list of that year and the subsequent list. The third column gives the number of new public companies added to the Best Companies list of that year. The fourth column contains the number of companies on the previous Best Companies list that no longer feature in the current list or are no longer public. The sample period is 1984 through 2011.

mation date. The table also gives the number of firms added to and dropped from the list. As is intuitive, job satisfaction is reasonably persistent and characterized by some degree of path dependency (Collis \& Montgomery, 1995). But it is not permanent - about one-third of traded firms drop off the list each year, perhaps due to changes in HRM policy. Thus, path dependency is not insurmountable. Between 1984 and 2011, 245 separate public firms were included in a list, corresponding to 1,682 firm-year observations (885 excluding years when the list was not updated).

The Best Companies list has been used in previous research. The results in this paper were originally documented by Edmans (2011), who focused on the finance (rather than management) implications of the findings. That paper studied 1984 through 2009 and thus missed the volatile years of 2010 and 2011 in the aftermath of the financial crisis. The other studies do not investi- 
gate long-run stock returns. ${ }^{5}$ Faleye and Trahan (2011) and Lau and May (1998) studied accounting profits, which suffer from reverse causality. Filbeck and Preece (2003) examined the relationship between inclusion in the 1998 Fortune list and stock returns from 1987 to 1999, and thus in their study, satisfaction may be caused by strong past stock returns. They also find that Best Companies do not outperform size- and industry-matched benchmarks. Fulmer, Gerhart, and Scott (2003) found that returns between 1995 and 2000 to the Best Companies in the 1998 list did not outperform those of their peers. Simon and DeVaro (2006) showed that the Best Companies have high customer satisfaction and Fulmer and colleagues (2003) documented higher employee loyalty, but neither studied firm value. Kruse and colleagues (2012) used the Best Companies list to study the separate question of how group incentive methods affect job satisfaction and found that group incentive pay in a Best Company reduces voluntary turnover and increases employee intent to stay and return on equity.

\section{Methodology}

0 ne concern is that high returns to the Best Companies arise purely due to a publicity effect from list inclusion rather than from job satisfaction. I thus calculated returns from the month after list announcement. Note that this leads to the results being understated, as they omit any "legitimate" increase upon announcement due to the market recognizing the benefits of satisfaction. ${ }^{6}$ The first list was published in a book in March 1984. I formed an equal-weighted portfolio containing the 74 publicly traded Best Companies as of April 1, 1984, and measured its returns from April 1984 to February 1993. I reformed the portfolio as of March 1, 1993, to contain the 65 firms included in the new list and calculated returns through January 1998. I repeated this process until December $2011 .{ }^{7}$

\footnotetext{
${ }^{5}$ The exception is Goenner (2008), who studied a much shorter time period and without most of the controls in this study.

${ }^{6}$ Faleye and Trahan (2011) found a positive return to list inclusion.

${ }^{7}$ If a Best Company is initially private but goes public before the next list, I add it to the portfolio from the first full month after it starts trading. For example, the Best Companies portfolio features 78 firms from 1984 to 1993, since four firms in the initial list became public over that period.
}

To ensure that any high returns to the Best Companies are not simply compensation for risk, I use the Carhart (1997) four-factor model. This model controls for four risk factors and is the most commonly used asset pricing model in finance. It is given as follows:

$$
\begin{array}{r}
R_{t}=\alpha+\beta_{\mathrm{MKT}} \mathrm{MKT}+\beta_{\mathrm{HML}} \mathrm{HML}+\beta_{\mathrm{SMB}} \mathrm{SMB} \\
+\beta_{\mathrm{MOM}} \mathrm{MOM}+\varepsilon_{t}
\end{array}
$$

where:

$R_{t}$ is the return on the Best Companies portfolio in month $t$ in excess of a benchmark, described below.

$\alpha$ is an intercept that captures the excess return that the Best Companies earn over and above their benchmark, after controlling for risk. This alpha is the key variable of interest.

$M K T_{t}$ is the return on the market portfolio in excess of the risk-free rate. This represents a market factor. The return on the market portfolio is measured using the CRSP value-weighted index. $\beta_{M K T}$ represents the sensitivity of the Best Companies' return to the return on the market, and is known as the beta in a Capital Asset Pricing Model. It measures how much market risk the Best Companies bear.

$\mathrm{HML}_{t}$ is the return on a zero-investment portfolio, which is long (short) high (low) book-market stocks. $\beta_{H M L}$ represents the sensitivity of the Best Companies to a value factor, and measures how much "value" risk the Best Companies bear.

$\mathrm{SMB}_{t}$ is the return on a zero-investment portfolio, which is long (short) small (large) stocks. $\beta_{\mathrm{SMB}}$ represents the sensitivity of the Best Companies to a size factor, and measures how much "size" risk the Best Companies bear.

$\mathrm{MOM}_{t}$ is the return on a zero-investment portfolio which is long (short) stocks with high (low) past returns. $\beta_{\mathrm{MOM}}$ represents the sensitivity of the Best Companies to a momentum factor, and measures how much "momentum" risk the Best Companies bear.

$\varepsilon_{t}$ is an error term that is uncorrelated with the independent variables. ${ }^{8}$

I measure the returns $R_{t}$ over three different

\footnotetext{
${ }^{8}$ I calculate standard errors using Newey and West (1987), which allows for $\varepsilon_{t}$ to be heteroskedastic and serially correlated.
} 
benchmarks. The first is the risk-free rate from Ibbotson Associates. The second is an industrymatched portfolio using the 49-industry classification of Fama and French (1997). This is to ensure that any high returns to the Best Companies do not arise simply because they are in industries that happened to enjoy strong returns. The third is the characteristics-adjusted benchmark used by Daniel, Grinblatt, Titman, and Wermers (1997) and Wermers (2004), ${ }^{9}$ which matches each Best Company to a portfolio of stocks with similar size, book-market ratio, and momentum. This is to ensure that any high returns to the Best Companies do not arise simply because of their size, book-market, and momentum characteristics. ${ }^{10}$

\section{Results}

\section{Stock Refurns}

P anel $A$ in Table 4 shows that the Best Companies portfolio generates significant returns over all benchmarks. The alpha is $0.31 \%$ monthly (3.8\% annually) above the risk-free rate, $0.19 \%(2.3 \%)$ controlling for industries, and $0.24 \%(2.9 \%)$ controlling for firm characteristics.

One concern is that the results of Panel A may be driven by outliers. For example, Google was on the Best Companies list for many years and enjoyed extremely strong performance. If the high returns of the Best Companies portfolio are driven by a couple of outliers, then it may not be that job satisfaction in general is associated with good performance, but that a few exceptional performers happen also to exhibit high job satisfaction. I checked the robustness of the results to outliers by winsorizing ${ }^{11}$ the $x \%$ highest and $x \%$ lowest returns exhibited by the Best Companies over the time period, for $x=\{5,10\}$. Panels B and C show that the alphas for the winsorized portfolios are in fact slightly higher

${ }^{9}$ The benchmarks are available via http://www.smith.umd.edu/faculty/ rwermers/ftpsite/Dgtw/coverpage.htm.

${ }^{10}$ The finance literature has found that stocks with small size, high value (a low market price compared to their book value), and high momentum (strong recent performance) tend to outperform.

${ }^{11}$ Winsorization involves replacing any returns above the $(100-x)$ th percentile with the $(100-x)$ th percentile return, and any returns below the $x$ th percentile with the $x$ th percentile return (i.e., it trims the tails of the distribution).

\section{Table 4}

Risk-Adjusted Returns

\begin{tabular}{|c|c|c|c|}
\hline & \multicolumn{3}{|c|}{ Excess returns over } \\
\hline & Risk-free & Industry & Characteristics \\
\hline \multicolumn{4}{|c|}{ Panel A: Unwinsorized } \\
\hline \multirow[t]{2}{*}{$\alpha$} & 0.31 & 0.19 & 0.24 \\
\hline & $(3.52)^{* * *}$ & $(2.90)^{* * *}$ & $(2.95)^{* * *}$ \\
\hline \multirow[t]{2}{*}{$\beta_{M K T}$} & 1.07 & 0.06 & 0.08 \\
\hline & $(44.71)^{* * *}$ & $(3.65)^{* * *}$ & $(3.57)^{* * *}$ \\
\hline \multirow[t]{2}{*}{$\beta_{\text {HML }}$} & 0.02 & 0.08 & 0.01 \\
\hline & $(0.50)$ & $(3.15)^{* * *}$ & $(0.41)$ \\
\hline \multirow[t]{2}{*}{$\beta_{S M B}$} & 0.17 & 0.15 & 0.05 \\
\hline & $(3.69)^{* * *}$ & $(5.76)^{* * *}$ & (1.41) \\
\hline \multirow[t]{2}{*}{$\beta_{\text {MOM }}$} & -0.14 & -0.07 & -0.09 \\
\hline & $(-6.43)^{* * *}$ & $(-3.54)^{* * *}$ & $(-4.89)^{* * *}$ \\
\hline \multicolumn{4}{|c|}{ Panel B: Winsorized at 5\% } \\
\hline \multirow[t]{2}{*}{$\alpha$} & 0.33 & 0.22 & 0.27 \\
\hline & $(3.56)^{* * *}$ & $(2.77)^{* * *}$ & $(3.09)^{* * *}$ \\
\hline \multicolumn{4}{|c|}{ Panel C: Winsorized at 10\% } \\
\hline \multirow[t]{2}{*}{$\alpha$} & 0.37 & 0.26 & 0.32 \\
\hline & $(4.14)^{* * *}$ & $(3.23)^{* * *}$ & $(3.66)^{* * *}$ \\
\hline No. of obs & 333 & 333 & 333 \\
\hline
\end{tabular}

* Significant at the $10 \%$ level; ** significant at the $5 \%$ level; $* * *$ significant at the $1 \%$ level.

These are monthly regressions of returns to a portfolio of the Best Companies on the four Carhart (1997) factors: $M K T, H M L, S M B$, and MOM. The dependent variable is the portfolio return less either the risk-free rate, the industrymatched portfolio return, or the characteristics-matched portfolio return. Panel A contains unwinsorized returns, Panel B contains returns winsorized at the $5 \%$ and $95 \%$ levels, and Panel C contains returns winsorized at the $10 \%$ and $90 \%$ levels. The alpha is the excess risk-adjusted return; $t$-statistics are in parentheses. The sample period is April 1984 through December 2011.

than in Panel A. The results in the other tables in this paper are also robust to winsorization.

While Table 4 shows that the Best Companies' outperformance is not due to their sensitivity to the Carhart (1997) factors, industry affiliation, size, value, or momentum, it may be due to other firm characteristics. Adding additional firm characteristics requires a different econometric approach. In Edmans (2011) I used the Fama and MacBeth (1973) regression technique to show that the results are also robust to controlling for dividend yield, trading volume, the firm's stock price, and additional past return measures. 


\section{Earnings Announcements}

I previously explained that the choice to study future stock returns, rather than earnings, was because the analysis of earnings is more susceptible to concerns about reverse causality. A positive correlation between current satisfaction and current earnings could arise because earnings cause satisfaction. But there is a way to study earnings that addresses reverse causality. This approach involves comparing a firm's earnings announcements to Wall Street analysts' prior forecasts. Analysts should consider all public tangible information-including current earnings-when forecasting future earnings. Thus, if high current satisfaction was the result of high current earnings, analysts should take these high current earnings into account and forecast high future earnings. As a result, the firm's actual earnings announcement should be no higher than the earnings forecast. A firm can systematically beat its earnings forecast only if it enjoys a valuable asset that the market does not take into account, such as job satisfaction.

I thus study the difference between earnings announcements and prior analyst expectations-the "earnings surprise"-for the Best Companies and their peers. This analysis has two objectives. First, it addresses concerns that the high returns of the Best Companies arise because these companies exhibit high risk that is not captured by the Carhart (1997) model. Second, it demonstrates a channel through which job satisfaction improves stock returns. While job satisfaction is not directly valued by the market (because it is intangible), it generates future tangible outcomes that are valued by the market (e.g., earnings announcements).

I run the following regression:

$$
\text { Surprise }_{i t}=b_{0}+b_{l} X_{i t}+b_{2} Z_{i t-j}+\varepsilon_{i t}
$$

Surprise $_{i t}$ is the one- or two-year earnings surprise, or the long-term growth surprise. The one-year earnings surprise is the actual earnings per share (EPS) for company $i$ in the fiscal year ending in year $t$ minus the median Institutional Brokers' Estimate System (I/B/E/S) analyst forecast, deflated by the stock price at fiscal year end. ${ }^{12}$ The two-year earnings surprise is calculated similarly. As is standard, I remove observations for which the forecast error is larger than $10 \%$ of the price. The long-run growth surprise is the actual five-year EPS growth from $\mathrm{I} / \mathrm{B} / \mathrm{E} / \mathrm{S}$ minus the consensus long-run growth forecast. Since this measure is already a percentage, I do not deflate it. $X_{i t}$ is an indicator variable for whether the firm was in the most recent Best Companies list. $Z_{i t-j}$ is a vector of control variables: the log book-to-market ratio and the log market value at year end. These are calculated either one, two, or five years before the forecast period end date (i.e., $j=1,2$, or 5). I estimate Equation 2 using a pooled regression with year fixed effects.

The results are shown in Table 5 . The one- and T5 two-year earnings surprises are significantly greater for the Best Companies at the 1\% level. These results are robust to adding the book-tomarket ratio but not size as a control. However, the results for five-year earnings growth are robust to all controls. The stronger results for long-term growth are consistent with the view that satisfaction is a long-run investment. ${ }^{13}$

Table 6 examines whether these positive earn- T6 ings announcements improve the stock price. I take all earnings announcement dates from April 1984 through December 2011 from I/B/E/S and calculate three-day $(-1,+1)$ returns in excess of the Capital Asset Pricing Model. ${ }^{14}$ Panel A shows that the Best Companies enjoy average excess returns of $0.37 \%$, significantly different from the $0.10 \%$ enjoyed by other firms. Panel B shows the results of a similar regression analysis to Table 5 ,

\footnotetext{
${ }^{12} \mathrm{The} \mathrm{I} / \mathrm{B} / \mathrm{E} / \mathrm{S}$ consensus forecast is taken eight months before the end of the forecast period (i.e., four months after the previous fiscal year end). Since most annual reports are filed within three months of the fiscal year end, this ensures that analysts know prior earnings when making their forecasts. For the two-year earnings surprise, the consensus forecast is taken 20 months before year end. For the long-run growth surprise, the consensus forecast is taken 56 months prior.

${ }^{13}$ For robustness, I also calculate the earnings surprise scaling by assets per share rather than the stock price, use the mean rather than median forecast as consensus, and drop observations for which there are fewer than five analyst forecasts to ensure that the $\mathrm{I} / \mathrm{B} / \mathrm{E} / \mathrm{S}$ consensus is an accurate proxy for investor expectations. The results are barely affected by any of these changes.

${ }^{14}$ The model is estimated using up to 255 trading days, ending 46 days before the event date. Results are very similar for five-day returns, and with different benchmarks.
} 


\section{Table 5}

\section{Earnings Surprises}

\begin{tabular}{|c|c|c|c|}
\hline & (1) & (2) & (3) \\
\hline \multicolumn{4}{|l|}{$\begin{array}{l}\text { Panel A: } \\
\text { 1-year earnings }\end{array}$} \\
\hline \multirow[t]{2}{*}{ Best Companies } & 3.50 & 3.07 & -1.06 \\
\hline & $(5.15)^{* * *}$ & $(4.53)^{\text {*** }}$ & $(-1.54)$ \\
\hline \multirow[t]{2}{*}{ BM } & & -0.11 & -0.34 \\
\hline & & $(-11.62)^{* * *}$ & $(-3.53)^{* * *}$ \\
\hline \multirow[t]{2}{*}{ Size } & & & 1.72 \\
\hline & & & $(30.86)^{* * *}$ \\
\hline No. of obs & 81,400 & 77,536 & 77,536 \\
\hline \multicolumn{4}{|l|}{$\begin{array}{c}\text { Panel B: } \\
\text { 2-year earnings }\end{array}$} \\
\hline \multirow[t]{2}{*}{ Best Companies } & 3.62 & 3.72 & -0.02 \\
\hline & $(4.42)^{* * *}$ & $(4.53)^{* * *}$ & $(-0.02)$ \\
\hline \multirow[t]{2}{*}{ BM } & & 0.33 & 1.08 \\
\hline & & $(2.51)^{* *}$ & $(7.98)^{* * *}$ \\
\hline \multirow[t]{2}{*}{ Size } & & & 1.75 \\
\hline & & & $(22.25)^{* * *}$ \\
\hline No. of obs & 55,739 & 53,625 & 53,625 \\
\hline \multicolumn{4}{|l|}{$\begin{array}{c}\text { Panel C: } \\
\text { Long-term growth }\end{array}$} \\
\hline \multirow[t]{2}{*}{ Best Companies } & 2.10 & 3.27 & 1.09 \\
\hline & $(4.01)^{* * *}$ & $(6.23)^{* * *}$ & $(2.03)^{* *}$ \\
\hline \multirow[t]{2}{*}{ BM } & & 2.34 & 2.85 \\
\hline & & $(24.68)^{* * *}$ & $(29.03)^{* * *}$ \\
\hline \multirow[t]{2}{*}{ Size } & & & 1.06 \\
\hline & & & $(19.16)^{* * *}$ \\
\hline No. of obs & 41,444 & 40,026 & 40,026 \\
\hline
\end{tabular}

* Significant at the $10 \%$ level; ** significant at the $5 \%$ level; $* * *$ significant at the $1 \%$ level.

This table contains regressions of earnings surprises on an indicator variable for whether the firm was in the most recent list of the "100 Best Companies to Work For in America" (Best Companies) and controls ( $B M$, log book-to-market, and Size, log market equity calculated at the previous year end). The 1- (2-) year earnings surprise is the actual EPS minus the $\mathrm{I} / \mathrm{B} / \mathrm{E} / \mathrm{S}$ median analyst forecast 8 (20) months prior to the end of the forecast period, scaled by the stock price. The long-term growth surprise is the actual five-year annualized EPS growth rate minus the I/B/E/S median analyst long-term growth forecast from 56 months earlier. The Best Companies indicator and control variables are taken from the same month as the I/B/E/S median forecast. Panel A (B) contains the results for 1- (2-) year earnings surprises; Panel $C$ contains the results for long-term growth surprises. All coefficients are multiplied by 1,000. All regressions include year fixed effects and a constant, not reported for brevity; $t$-statistics are in parentheses. The sample period is April 1984 through December 2011.

using year fixed effects and controls. Regardless of the controls used, the Best Companies indicator is
Table 6 Earnings Announcement Refurns

\begin{tabular}{|l|c|c|c|}
\hline & \multicolumn{2}{|c|}{ Best company } & Other firms \\
\hline Panel A: univariate comparisons & \multicolumn{3}{|c|}{$(2.37)^{* *}$} \\
\hline CAR & \multicolumn{2}{|c|}{0.37} & 0.10 \\
\hline No. of obs & \multicolumn{2}{|c|}{5,791} & 316,515 \\
\hline t-Stat (difference from 0) & \multicolumn{2}{|c|}{$(4.45)^{* * *}$} & $(6.07)^{* * *}$ \\
\hline t-Stat (difference in means) & \multicolumn{3}{|c|}{$(3)$} \\
\hline Panel B: regressions & $(1)$ & $(2)$ & 0.32 \\
\hline Best Companies & 0.29 & 0.41 & $(2.74)^{* * *}$ \\
\hline & $(2.46)^{* *}$ & $(3.53)^{* * *}$ & 0.30 \\
\hline BM & & 0.28 & $(16.17)^{* * *}$ \\
\hline & & $(15.71)^{* * *}$ & 0.04 \\
\hline Size & & & $(3.85)^{* * *}$ \\
\hline & & & 302,824 \\
\hline No. of obs & 322,306 & 302,824 & \\
\hline
\end{tabular}

* Significant at the $10 \%$ level; ** significant at the $5 \%$ level; *** significant at the $1 \%$ level.

This table contains $(-1,+1)$ excess returns to quarterly earnings announcements. Excess returns are calculated above a market model in which the coefficients are estimated over a 255-day period ending 46 days before the earnings announcement. Panel A compares the average announcement returns to firms included in the most recent list of the "100 Best Companies to Work For in America" with the returns to all other firms. Panel B regresses announcement returns on an indicator variable for whether the firm was in the most recent Best Companies list (Best Companies) and controls $B M$, log book-to-market, and Size, log market equity calculated at the previous year-end. These regressions include year fixed effects and a constant, not reported for brevity; $t$-statistics are in parentheses. The sample period is April 1984 through December 2011.

significant. For example, the Best Companies exhibit a $0.32 \%$ higher announcement return than companies of similar size and book-to-market. With four quarterly announcements per year, earnings surprises account for over $1.2 \%$ of the Best Companies' outperformance. This is a meaningful portion of the $2.9 \%$ alpha over characteristics benchmarks (shown in Table 4).

\section{Discussion}

This paper's results have three main implications. The first is that job satisfaction is positively linked to firm value, using a measure of firm value (future stock returns) that has several advantages over prior literature. Since the implications for the link between job satisfaction and firm value have been discussed above, the rest of 
the paper will focus on the other two implications-corporate social responsibility and the mispricing of intangibles-as well as some limitations.

\section{Implications for Corporate Social Responsibility}

The second implication is that corporate social responsibility (CSR) may be positively linked to firm value. CSR involves firms considering the interests of stakeholders other than shareholders, such as employees, customers, and the environment (Clarkson, 1995; Donaldson \& Preston, 1995; Freeman, 1984; Shrivastava, 1995). Since the Best Companies exhibit particularly high concern for employees, this study also generates implications for CSR. In particular, the approach taken by this paper-examining the relationship between job satisfaction and firm value-can also be applied to study the link between CSR and firm value.

\section{The Link in Theory}

The literature on CSR and firm value loosely parallels the literature on job satisfaction and firm value. Just as the HRM literature has identified several theoretical benefits of job satisfaction, the management literature has identified several theoretical benefits of CSR. Cornell and Shapiro (1987) argued that CSR improves the value of a firm's implicit claims with its stakeholders. For example, while an employee's wage can be stipulated in his contract, it is harder to specify working conditions. A firm with a reputation for treating its employees well will be able to implicitly promise good working conditions, helping recruitment. Jones (1995) used the term "instrumental stakeholder management" to highlight the firm value benefits from taking into account stakeholders' interests. Specifically, CSR can improve brand image (Moskowitz, 1972), foster customer goodwill (Solomon \& Hanson, 1985), reduce the likelihood of negative regulatory action (Freeman, 1984; Porter \& van der Linde, 1995), attract and retain high-quality employees (Greening \& Turban, 2000; Turban \& Greening, 1997), and attract capital from socially responsible investors (Cheng, Ioannou, \& Serafeim, 2011).

\section{The Link in Practice}

Like job satisfaction, while the benefits of CSR are relatively clear in theory, empirically documenting them is harder. There is some evidence of a positive correlation between CSR and various firm outcomes. Turban and Greening (1997) showed that CSR ratings are positively related to firms' reputations as employers, suggesting that CSR aids recruitment. Bragdon and Marlin (1972), Parket and Eilbirt (1975), Cochran and Wood (1984), and McGuire, Sundgren, and Schneeweis (1988) found a positive link to accounting performance. More generally, the metaanalyses of Roman, Hayibor, and Agle (1999) and Margolis and Walsh (2003) documented that more studies find a positive than negative relationship between CSR and financial performance.

But, as with the job satisfaction literature, reverse causality is an issue. Cochran and Wood (1984, p. 55) caveat their results by noting that "causality should be investigated. No work to date has statistically demonstrated the direction of causation between these two variables [CSR and accounting performance]." The "slack resources theory" of Waddock and Graves (1997a) argues that financial performance can cause CSR as wellperforming firms have the financial resources to invest in stakeholders; indeed, they find a bidirectional relationship. The meta-analysis of Orlitzky, Schmidt, and Rynes (2003) similarly concluded that "the relationship tends to be bidirectional and simultaneous."

Some previous studies also do not take into account the cost of CSR. Aupperle, Carroll, and Hatfield (1985) and McWilliams and Siegel (2000) highlighted additional methodological problems: Studies often consider short time horizons, examine only a small number of firms or a single industry, fail to control for risk, and do not employ tests of significance. McWilliams and Siegel (2000, p. 603) concluded that existing studies "suffer from several important theoretical and empirical limitations" and constitute "flawed empirical analysis." Both papers, using methods that address the issues they raise, find no relationship between CSR and accounting performance. Ullmann's (1985, p. 545) meta-analysis concluded 
that "the more elaborate studies seem to converge towards rejecting any relationship between social performance and economic success," and Arlow and Gannon's (1982, p. 240) meta-analysis found that "economic performance, at least in the short run, is not directly linked, in either a positive or negative fashion, to social responsiveness."

More recent research has uncovered some benefits to CSR that are robust to the above concerns. Ioannou and Serafeim (2010) found that CSR improves analyst recommendations, and Cheng, Ioannou, and Serafeim (2011) showed that CSR increases access to finance by using an instrumental variable to identify causality. While these studies are useful in identifying specific channels through which CSR can help, CSR might worsen firm value through others. Thus, to draw overall conclusions on the effect of CSR on firm value, we must examine stock prices. They capture all the potential mechanisms through which CSR may have an effect (analyst recommendations, access to finance, recruitment, customer goodwill, etc.) as well as the cost. In particular, one hypothesized advantage of CSR is that it reduces firm risk (Cornell \& Shapiro, 1987), but there is no accepted way to adjust accounting variables for risk.

\section{This Paper's Approach}

Just as the use of stock returns can shed light on the effect of job satisfaction on firm value, it can also shed light on the effect of CSR on firm value. Stock returns tackle reverse causality, take into account the costs of CSR and the appropriate weighting of the different outcome variables, and allow for risk adjustment. While stock returns are almost never used to study job satisfaction, many existing papers do use them to investigate CSR. However, several studies suffer from methodological issues. Moskowitz (1972) found that socially responsible stocks exhibit higher stock returns and Vance (1975) found the opposite, but both studies ignored dividends, failed to control for risk, and considered small samples. Abbott and Monsen (1979) incorporated dividends but did not control for risk, and found no relationship between CSR and stock returns. When controlling for risk, Alexander and Buchholz (1978) also found no relationship. The papers that do employ modern tech- niques uncover mixed results: In the finance literature, a large number of studies find a zero or negative effect of CSR on stock returns (see Edmans, 2011, for a survey).

These findings seem to contradict the theoretical benefits of CSR identified by the management literature, and instead support the economics and finance literatures' view on CSR. Just as these literatures view job satisfaction being at the expense of shareholders, they also view caring excessively for other stakeholders as costly to shareholders (Friedman, 1970). Similarly, traditional portfolio theory argues that socially responsible investing (SRI) worsens returns. SRI involves using "screens" to ensure that the investor selects only companies that are socially responsible. This may involve positive screens, where the investor "screens in" companies that surpass an upper bar for a CSR criterion (e.g., employee welfare), and negative screens, where the investor "screens out" companies that fall below a lower bar. Regardless of the type of screen, the conventional view is that they worsen returns by restricting an investor's choice set. Mathematically, a constrained optimization is never better than an unconstrained optimization.

Some previous papers consider CSR as a homogeneous entity, by studying the stock returns to companies that are socially responsible in general. But CSR comprises a myriad of dimensions. While some dimensions may be beneficial to shareholder value, it is unclear how others benefit the firm. Lumping together several different dimensionssome beneficial, others not-may lead to insignificant results. Thus, this paper's approach is to study one particular dimension of CSR that has an especially strong theoretical link to firm value (described earlier): employee welfare. Traditional portfolio theory suggests that any SRI screen worsens performance, and so it is sufficient to uncover one screen that improves performance to contradict it. Job satisfaction is a screen frequently employed by SRI mutual funds, particularly those concerned with employee welfare.

In contrast to the finance literature's view of SRI, this study finds an SRI screen that can improve returns. To my knowledge, this is the first paper that identifies a CSR dimension that 
improves stock returns, over a long time period and after controlling for risk. Why might CSR improve stock returns, in contrary to conventional wisdom? A firm's concern for other stakeholders, such as employees, may ultimately benefit shareholders (the first implication of the paper), yet not be priced by the market because "stakeholder capital" — the additional firm value created by enhancing stakeholder goodwill-is intangible.

\section{Implications for the Mispricing of Intangibles}

Indeed, the mispricing of intangible assets- that intangibles are valuable but their value is not immediately recognized by the market-is the third and final implication of this paper. Intangibles are assets that are not physical in nature, and so cannot be seen or physically measured. Examples include intellectual property (patents and trademarks), brand, customer loyalty, and human capital. Previous studies have identified various intangibles that are not fully valued: Firms with high $R \& D$ as measured by expenditure (Chan, Lakonishok, \& Sougiannis, 2001; Lev \& Sougiannis, 1996), advertising as measured by expenditure (Chan et al., 2001), patent quality as measured by citations (Deng, Lev, \& Narin, 1999), and software quality as measured by development costs (Aboody \& Lev, 1998) all earn higher long-run returns. This study aims not only to extend earlier results to another category of intangibles, but also to shed light on the causes of the misvaluation found by previous studies.

Previous papers argued that intangibles are not incorporated because the market lacks information on their value. Since they cannot be measured, it is hard for managers to credibly certify their value to outsiders. While R\&D spending can be observed in an income statement, this is an input measure uninformative of its quality or success. Even if information is available on an output measure such as patent citations, the market may ignore it if it is not salient (Deng, Lev, and Narin's citation measure had to be hand-constructed) or is about small firms that are not widely followed.

I evaluate the above hypothesis by using a quite different measure of intangibles, which the market does have information about. The Best Companies list measures satisfaction (an output) rather than expenditure on employee-friendly programs (an input). It is particularly visible: Since 1998 it has been widely disseminated by Fortune, and it covers large companies. Its release attracts widespread attention, because it discloses information on many companies simultaneously. Listed companies often heavily advertise that they are a "Best Company to Work For," such as on the front page of their Web site. Thus, the list is a potential solution to the lack of information that surrounds other intangibles; it is widely publicized, independent verification of a company's level of job satisfaction. If lack of information is the main reason for previous misvaluation findings, there should be no misvaluation of the Best Companies.

However, I find that the stock market does not fully react to the Best Companies list. Even though I wait a full month after list publication before calculating my returns, I still find significant outperformance. In Edmans (2011) I showed that the outperformance is even stronger since 1998, even though the list was publicized by Fortune and even more visible. This mispricing result suggests that the misvaluation of intangibles found by prior research stems not purely from lack of information, but from other factors. It may be that the stock market uses traditional valuation methodologies devised for the 20th-century firm and based on physical assets, which cannot accommodate intangibles easily. As a result, the market takes a very long time to incorporate intangibles into the stock price: In Edmans (2011) I showed that full incorporation takes as long as four to five years.

If even independently verified, widely publicized intangible assets are not valued by the market, this implies that intangibles in general-the vast majority of which have no equivalent of the Best Companies list to verify and publicize them-will also not be immediately valued. These include other intangibles studied by the management literature, such as customer goodwill, brands, and organizational culture. The paper's results support managerial myopia theories (e.g., Edmans, 2009; Stein, 1988), in which managers 
underinvest in intangibles because the market values them only in the very long run. This conclusion in turn has implications for how to design organizations to encourage long-term growth. We currently evaluate managers according to quarterly earnings announcements. But to induce intangible investment, we must pay them based on the stock price far into the future (Edmans, Gabaix, Sadzik, \& Sannikov, 2012).

\section{Limitations}

This paper's use of stock returns helps to address reverse causality because, if job satisfaction were caused by good performance (or any other public, tangible variable), the stock price would already be high today and so we should not expect high returns in the future. It also uses a battery of controls (such as industry performance, risk, and firm characteristics) to address concerns about omitted variables. However, even though these techniques address several alternative explanations, others remain. Studying stock returns addresses reverse causality from performance to satisfaction if there is no private informationpublic information about a firm's profitability should already be in the stock price. However, if employees have private information about their firm's future stock returns, those with positive information may report higher satisfaction today. Thus, the link between current satisfaction and future stock returns arises because the latter causes the former.

This explanation is unlikely for a number of reasons. Prior research suggests that employees do not have private information: Benartzi (2001) showed that employees make wrong decisions when investing their $401(\mathrm{k})$ plans in their own firms, and Bergman and Jenter (2007) found that firms are able to lower total pay by granting their workers overvalued options in place of salary. Even if employees do have private information, it is likely to be about short-term returns, given that managers are unable to forecast returns past 100 days (Jenter, Lewellen, \& Warner, 2011). Since they must return the questionnaires by the end of June, but returns are calculated from the following February, this will not affect the results. $^{15}$

Second, the link between satisfaction and returns may arise because a third unobservable variable, such as good management (Bloom, Kretschmer, \& Van Reenen, 2009, 2011; Waddock \& Graves, 1997b), causes both-that is, the Best Companies indicator proxies for an omitted variable. While I rule out correlation with industries, risk, and an extensive list of observable characteristics, by their very nature unobservables cannot be used as controls. If the results were entirely driven by the above noncausal explanations, increasing job satisfaction would not improve firm performance. But other conclusions from this paper would be unaffected. It still remains that an SRI investor could have earned excess returns by buying the Best Companies, and that the market does not incorporate intangibles (be they satisfaction, good management, or workers' private information) even when they are made public.

A third limitation relates to the generalizability of the results. One issue is generalizability to the overall distribution of job satisfaction. The Best Companies list considers only firms in the right tail of job satisfaction, since it includes only 100 firms per year. It may be that job satisfaction matters only when it reaches very high levels, and that there is little difference for firm value between low and moderate job satisfaction. In Edmans (2011) I showed that firms that dropped off the Best Companies list (and thus likely continue to enjoy above-average job satisfaction, even though they are no longer in the top 100) still slightly outperform their peers. These results provide suggestive evidence that moderate job satisfaction is also correlated with firm value.

A second issue concerns generalizability from job satisfaction to other dimensions of CSR. While the paper shows high returns to job satisfaction, its results may not extend to other CSR dimensions (e.g., environmental policy). Note that traditional portfolio theory predicts that any

${ }^{15}$ Furthermore, the Best Companies survey does not simply ask employees to rate their satisfaction, which could indeed lead to optimistic employees reporting high satisfaction. Instead, the survey includes very specific questions (see Table 1) that aim to specifically target satisfaction rather than optimism. 
CSR screen reduces investment returns by restricting the investor's choice set, so finding even one screen that improves returns is sufficient to challenge this view. Thus, these findings provide motivation for extending the investigation to other screens. If other forms of "stakeholder capital" also benefit shareholders (e.g., low pollution improves a firm's corporate image) and are also undervalued by the market, certain other screens may also improve returns. Studying other dimensions of CSR would be a fruitful topic for future research.

\section{Conclusion}

T his paper finds that firms with high levels of job satisfaction, as measured by inclusion in the list of the "Best Companies to Work For in America," generate high long-run stock returns. The results are robust to controls for risk, industries, and firm characteristics, and the removal of outliers. The use of future stock returns, rather than standard performance measures, reduces concerns of reverse causality and captures all potential channels (both benefits and costs) through which satisfaction can affect firm value. I also find that the Best Companies systematically beat analysts' earnings estimates. Both of these results suggest that job satisfaction is a valuable characteristic that is not fully valued by the market.

These results have three main implications. First, job satisfaction causes stronger corporate performance, as argued by HRM theories. Second, certain CSR dimensions can improve stock returns. Third, the market is slow to fully value intangible assets-even when they are independently verified by a highly visible survey. Instead, an intangible affects the stock price only when it later shows up in tangibles that are valued by the market, such as earnings announcements.

The implications for whether managers should invest in increasing job satisfaction (for example, through implementing an HPWS) are doubleedged. Job satisfaction is positively correlated with shareholder returns, but only in the long run. Even if managers are able to obtain external verification for their firms' levels of job satisfaction, for example through the Best Companies survey or outside consultants, the effect on the stock price is unlikely to be immediate. Even if intangible assets are independently verified and widely publicized, the market appears not to fully value them. In addition to the time lag between achieving high job satisfaction and this quality being valued by the stock market, it also takes time for managerial actions to feed through into job satisfaction.

Even if causal ambiguity is not an issue (i.e., the manager can identify which HRM practices of the Best Companies are leading to their high job satisfaction), Becker and Huselid (1996) noted that an HPWS is also characterized by path dependency (Collis \& Montgomery, 1995). Firms cannot simply implement these best practices immediately: They do not start with a blank sheet of paper, and HPWSs take time to develop. For example, changing from a unitarist to a pluralist system may take several years as the system is likely embedded in the organizational culture. But path dependency is not insurmountable, and firms are not prisoners to their past: Approximately one-third of the Best Companies list turns over each year. Change is possible; it just may take time. Thus, to encourage managers to invest for the long run, it may be necessary to insulate them from short-term stock price movements-for example, by giving them stock and options with long vesting periods.

\section{Acknowledgments}

I am very grateful to AMP Editor Donald Siegel, two anonymous reviewers, Matthew Bidwell, Peter Cappelli, Ed Diener, Tom Donaldson, Emilie Feldman, Adam Grant, Frank Schmidt, and Sandra Waddock for valuable feedback, and to Ryan Peters and Dominic Waltz for research assistance. Special thanks to Amy Lyman of the Great Place to Work Institute for answering several questions about the Best Companies survey and sharing information about the survey tools.

\section{References}

Abbott, W. F., \& Monsen, R. J. (1979). On the measurement of corporate social responsibility: Self-report disclosure as a method of measuring social involvement. Academy of Management Journal, 22, 501-515.

Aboody, D., \& Lev, B. (1998). The value relevance of intangibles: The case of software capitalization. Journal of Accounting Research, 36, 161-191.

Abowd, J. (1989). The effect of wage bargains on the stock market value of the firm. American Economic Review, 79, $774-800$. 
Alexander, G. J., \& Buchholz, R. A. (1978). Corporate social responsibility and stock market performance. Academy of Management Journal, 21, 479-486.

Allen, D. G., Bryant, P. C., \& Vardaman, J. M. (2010). Retaining talent: Replacing misconceptions with evidence-based strategies. Academy of Management Perspectives, 24, 48-64.

Arlow, P., \& Gannon, M. J. (1982). Social responsiveness, corporate structure and economic performance. Academy of Management Review, 7, 235-241.

Aupperle, K., Carroll, A., \& Hatfield, J. (1985). An empirical examination of the relationship between corporate social responsibility and profitability. Academy of Management Journal, 28, 446-463.

Barney, J. B. (1986). Organizational culture: Can it be a source of sustained competitive advantage? Academy of Management Review, 11, 656-665.

Barsade, S. G., \& Gibson, D. E. (2007). Why does affect matter in organizations? Academy of Management Perspectives, 21, 36-59.

Becker, B. E., \& Gerhart, B. (1996). The impact of human resource management on organizational performance: Progress and prospects. Academy of Management Journal, 39, 779-801.

Becker, B. E., \& Huselid, M. A. (1998). High performance work systems and firm performance: A synthesis of research and managerial implications. Research in Personnel and Human Resources Management, 16, 53-101.

Benartzi, S. (2001). Excessive extrapolation and the allocation of $401(\mathrm{k})$ accounts to company stock. Journal of Finance, 56, 1747-1764.

Bergman, N. K., \& Jenter, D. (2007). Employee sentiment and stock option compensation. Journal of Financial Economics, 84, 667-712.

Bloom, N., Kretschmer, T., \& Van Reenen, J. (2009). Work-life balance, management practices and productivity. In R. B. Freeman \& K. L. Shaw (Eds.), International differences in the business practices and productivity of firms (pp. 15-54). Chicago: University of Chicago Press.

Bloom, N., Kretschmer, T., \& Van Reenen, J. (2011). Are family-friendly workplace practices a valuable firm resource? Strategic Management Journal, 32, 343-367.

Bragdon, J. H., \& Marlin, J. T. (1972). Is pollution profitable? Risk Management, 19, 9-18.

Brayfield, A. H., \& Crockett, W. H. (1955). Employee attitudes and employee performance. Psychological Bulletin, 52(5), 396-424.

Cappelli, P., \& Neumark, D. (2001). Do "high-performance" work practices improve establishment-level outcomes? Industrial and Labor Relations Review, 54, 737775.

Carhart, M. (1997). On persistence in mutual fund performance. Journal of Finance, 52, 57-82.

Chan, L., Lakonishok, J., \& Sougiannis, T. (2001). The stock market valuation of research and development expenditures. Journal of Finance, 56, 2431-2456.

Cheng, B., Ioannou, I., \& Serafeim, G. (2011). Corporate social responsibility and access to finance. Available from http://ssrn.com/abstract $=1847085$
Clarkson, M. B. (1995). A stakeholder framework for analyzing and evaluating corporate social performance. Academy of Management Review, 20, 92-117.

Cochran, P. L., \& Wood, R. A. (1984). Corporate social responsibility and financial performance. Academy of Management Journal, 27, 42-56.

Collis, D. J., \& Montgomery, C. A. (1995). Competing on resources: Strategy for the 1990s. Harvard Business Review, 73, 118-128.

Combs, J., Liu, Y., Hall, A., \& Ketchen, D. (2006). How much do high-performance work practices matter? A meta-analysis of their effects on organizational performance. Personnel Psychology, 59, 501-528.

Cornell, B., \& Shapiro, A. (1987). Corporate stakeholders and corporate finance. Financial Management, 16, 5-14.

Daniel, K., Grinblatt, M., Titman, S., \& Wermers, R. (1997). Measuring mutual fund performance with characteristic-based benchmarks. Journal of Finance, 52, 1035-1058.

Delaney, J., \& Huselid, M. (1996). The impact of human resource management practices on perceptions of organizational performance. Academy of Management Journal, 39, 949-969.

Deng, Z., Lev, B., \& Narin, F. (1999). Science and technology as predictors of stock performance. Financial Analysts' Journal, 55, 20-32.

Dhrymes, P. J. (1998). Socially responsible investing: Is it profitable? In The investment research guide to socially responsible investing. Plano, TX: The Colloquium on Socially Responsible Investing.

Diltz, J. D. (1995). Does social screening affect portfolio performance? Journal of Investing Spring, 64-69.

Donaldson, T., \& Preston, L. E. (1995). The stakeholder theory of the corporation: Concepts, evidence, and implications. Academy of Management Review, 20, 65-91.

Edmans, A. (2009). Blockholder trading, market efficiency, and managerial myopia. Journal of Finance, 64, 19671998.

Edmans, A. (2011). Does the stock market fully value intangibles? Employee satisfaction and equity prices. Journal of Financial Economics, 101, 621-640.

Edmans, A., Gabaix, X., Sadzik, T., \& Sannikov, Y. (2012). Dynamic CEO compensation. Journal of Finance, 67, 1603-1648.

Faleye, O., \& Trahan, E. (2011). Labor-friendly corporate practices: Is what is good for employees good for shareholders? Journal of Business Ethics, 101, 1-27.

Fama, E. F. (1970). Efficient capital markets: A review of theory and empirical work. Journal of Finance, 25, 383417.

Fama, E. F., \& French, K. R. (1997). Industry costs of equity. Journal of Financial Economics, 43, 153-193.

Fama, E. F., \& MacBeth, J. D. (1973). Risk, return, and equilibrium: Empirical tests. Journal of Political Economy, 81, 607-636.

Filbeck, G., \& Preece, D. (2003). Fortune's best 100 companies to work for in America: Do they work for shareholders? Journal of Business Finance and Accounting, 30, 771-797. 
Fisher, C. D. (2010). Happiness at work. International Journal of Management Reviews, 12, 384-412.

Freeman, E. (1984). Strategic management: A stakeholder approach. Marshfield, MA: Pitman.

Friedman, M. (September 13, 1970). The social responsibility of business is to increase its profits. New York Times.

Fulmer, I. S., Gerhart, B., \& Scott, K. (2003). Are the 100 best better? An empirical investigation of the relationship between being a "great place to work" and firm performance. Personnel Psychology, 56, 965-993.

Goenner, C. (2008). Investing in Fortune's 100 best companies to work for in America. Journal of Economics, 34, $1-20$.

Gorton, G., \& Schmid, F. (2004). Capital, labor, and the firm: A study of German codetermination. Journal of the European Economic Association, 2, 863-905.

Greening, D. W., \& Turban, D. B. (2000). Corporate social performance as a competitive advantage in attracting a quality workforce. Business and Society, 39, 254-280.

Griffeth, R. W., Hom, P. W., \& Gaertner, S. (2000). A meta-analysis of antecedents and correlates of employee turnover: Update, moderator tests, and research implications for the next millennium. Journal of Management, 26, 463-488.

Harter, J. K., Schmidt, F. L., Asplund, J. W., Killham, E. A., \& Agrawal, S. (2010). Causal impact of employee work perceptions on the bottom line of organizations. Perspectives on Psychological Science, 5, 378-389.

Harter, J. K., Schmidt, F. L., \& Hayes, T. L. (2002). Business-unit-level relationship between employee satisfaction, employee engagement, and business outcomes: A meta-analysis. Journal of Applied Psychology, 87(2), 268 279.

Huselid, M. A. (1995). The impact of human resource management practices on turnover, productivity, and corporate financial performance. Academy of Management Journal, 38, 635-672.

Ioannou, I., \& Serafeim, G. (2010). The impact of corporate social responsibility on investment recommendations. Available from http://ssrn.com/abstract $=1507874$

Jenter, D., Lewellen, K., \& Warner, J. (2011). Security issue timing: What do managers know, and when do they know it? Journal of Finance, 66, 413-443.

Jones, T. M. (1995). Instrumental stakeholder theory: A synthesis of ethics and economics. Academy of Management Review, 20, 404-437.

Judge, T. A., Thoresen, C. J., Bono, J. E., \& Patton, G. K. (2001). The job satisfaction-job performance relationship: A qualitative and quantitative review. Psychological Bulletin, 127(3), 376-407.

Kohn, A. (1993). Why incentive plans cannot work. Harvard Business Review, 71, 54-64.

Konrad, A., \& Mangel, R. (2000). The impact of work-life programs on firm productivity. Strategic Management Journal, 21, 1227-1237.

Kruse, D. L., Blasi, J. R., \& Freeman, R. B. (2012). Does linking worker pay to firm performance help the best firms do even better? Available from http://ssrn.com/ abstract $=1985078$
Landy, F. J. (1989). Psychology of work behavior. Pacific Grove, CA: Brooks/Cole.

Lau, R. S. M., \& May, B. (1998). A win-win paradigm for quality of work life and business performance. Human Resource Development Quarterly, 9, 211-226.

Lee, T. W., Mitchell, T. R., Holtom, B. C., McDaniel, L. S., \& Hill, J. W. (1999). The unfolding model of voluntary turnover: A replication and extension. Academy of Management Journal, 42, 450-462.

Lev, B., \& Sougiannis, T. (1996). The capitalization, amortization, and value-relevance of $R \& D$. Journal of Accounting and Economics, 21, 107-138.

Levering, R., \& Moskowitz, M. (1993). The 100 best companies to work for in America. New York: Plume.

Levering, R., Moskowitz, M., \& Katz, M. (1984). The 100 best companies to work for in America. Reading, MA: Addison-Wesley.

Likert, R. L. (1961). The human organization. New York: McGraw-Hill.

Locke, E. A. (1965). The nature and causes of job satisfaction. In M. D. Dunnette (Ed.), Handbook of industrial/ organizational psychology (pp. 1297-1349). Chicago: Rand McNally.

Lyubomirsky, S., King, L., \& Diener, E. (2005). The benefits of frequent positive affect: Does happiness lead to success? Psychological Bulletin, 131(6), 803-855.

Margolis, J., \& Walsh, J. (2003). Misery loves companies: Rethinking social initiatives by business. Administrative Science Quarterly, 48, 268-305.

McGregor, D. (1960). The human side of enterprise. New York: McGraw-Hill.

McGuire, J. B., Sundgren, A., \& Schneeweis, T. (1988). Corporate social responsibility and firm financial performance. Academy of Management Journal, 31, 854-872.

McWilliams, A., \& Siegel, D. (2000). Corporate social responsibility and financial performance: Correlation or misspecification? Strategic Management Journal, 21, 603609.

Mitchell, T. R., Holtom, B. C., Lee, T. W., Sablynski, C. J., \& Erez, M. (2001). Why people stay: Using job embeddedness to predict voluntary turnover. Academy of Management Journal, 44, 1102-1121.

Moskowitz, M. (1972). Choosing socially responsible stocks. Business and Society, 1, 71-75.

Newey, W., \& West, K. (1987). A simple positive-definite heteroscedasticity and autocorrelation consistent covariance matrix. Econometrica, 55, 703-708.

Organ, D. W. (1977). A reappraisal and reinterpretation of the satisfaction-causes-performance hypothesis. Academy of Management Review, 2, 46-53.

Organ, D. W. (1988). Organizational citizenship behavior: The good soldier syndrome. Lexington, MA: Lexington Books.

Orlitzky, M., Schmidt, F. L., \& Rynes, S. L. (2003). Corporate social and financial performance: A meta-analysis. Organization Studies, 24, 403-441.

Ostroff, C. (1992). The relationship between satisfaction, attitudes, and performance: An organizational level analysis. Journal of Applied Psychology, 77, 963-974.

Parket, R., \& Eilbirt, H. (1975). Social responsibility: The underlying factors. Business Horizons, 18, 5-10. 
Perry-Smith, J. E., \& Blum, T. C. (2000). Work-family human resource bundles and perceived organizational performance. Academy of Management Journal, 43, 1107-1117.

Porter, M. E., \& van der Linde, C. (1995). Green and competitive: Ending the stalemate. Harvard Business Review, 73, 120-134.

Roman, R., Hayibor, S., \& Agle, B. (1999). The relationship between social and financial performance: Repainting a portrait. Business and Society, 38, 109-125.

Shrivastava, P. (1995). Ecocentric management for a risk society. Academy of Management Review, 20, 118-137.

Simon, D., \& DeVaro, J. (2006). Do the best companies to work for provide better customer satisfaction? Managerial and Decision Economics, 27, 667-683.

Solomon, R. C., \& Hanson, K. R. (1985). It's good business. New York: Atheneum.

Stein, J. C. (1988). Takeover threats and managerial myopia. Journal of Political Economy, 46, 61-80.

Taylor, F. (1911). The principles of scientific management. New York: Harper \& Brothers.

Tsao, A. (2003, August 28). A showdown at the checkout for Costco. BusinessWeek.

Turban, D. B., \& Greening, D. W. (1997). Corporate social performance and organizational attractiveness to pro- spective employees. Academy of Management Journal, 40, 658-672.

Ullmann, A. A. (1985). Data in search of a theory: A critical examination of the relationships among social performance, social disclosure, and economic performance. Academy of Management Review, 10, 540-577.

Vance, S. (1975). Are socially responsible corporations good investment risks? Management Review, 64, 18-24.

Vroom, V. H. (1964). Work and motivation. New York: Wiley.

Waddock, S. A., \& Graves, S. B. (1997a). The corporate social performance-financial performance link. Strategic Management Journal, 18, 303-319.

Waddock, S. A., \& Graves, S. B. (1997b). Quality of management and quality of stakeholder relations: Are they synonymous? Business and Society, 36, 250-279.

Wermers, R. (2004). Is money really "smart"? New evidence on the relation between mutual fund flows, manager behavior, and performance persistence. Available from http://ssrn.com/abstract $=414420$

Wernerfelt, B. (1984). The resource-based view of the firm. Strategic Management Journal, 5, 171-180.

Zimmerman, A. (2004, March 26). Costco's dilemma: Be kind to its workers, or Wall Street? Wall Street Journal (p. 1). 